\title{
Assimilation of Consonants in English and Assimilation of the Definite Article in Arabic
}

\author{
Hamada Shehdeh Abid Dawood ${ }^{1}$, Dr. Ahmad Atawneh ${ }^{2}$ \\ Hebron University, Faculty of Graduate Studies and Academic Research \\ English Department
}

\begin{abstract}
:
This paper aims at discussing the term assimilation. Assimilation is a phonological process where a sound looks like another neighboring sound. It includes progressive, regressive, coalescent, full and partial assimilation. In addition, contextual assimilation is subject to the environment of sounds where historical assimilation is resulted from the development of languages. In Arabic, it is clear that the /1/ sound in the definite article disappears if followed by coronal consonants. It is, however, concluded that the importance of assimilation is to make pronunciation of a word or speech easier.
\end{abstract}

\section{INTRODUCTION}

Assimilation is an everyday occurrence in every human language, and it is particularly common for nasal sounds (McMahon, 2002, p. 4). Thus, sounds in the environment of other sounds, across morpheme and word boundaries tend to undergo various phonological changes referred toas phonological processes (Ofulue et al, 2010, p. 49). Making a sound more like another in the same or next word in continuous utterance is called assimilation (Oxford Dictionary, 2008).

Assimilation usually occurs because two sounds share common features in place or manner. Thus, assimilation of consonants occurs when a consonant takes on features of another one. For instance, the sound $/ \mathrm{n} / \mathrm{becomes} / \mathrm{m} / \mathrm{in}$ certain environments; this is going to be discussed in detail later.

It is, however, believed that assimilation varies in extent according to speaking rate and style; itis more likely to be found in rapid, casual speech and less likely in slow, careful speech (Roach,1998, p.124). Moreover, it occurs either across word boundaries or within a word. If it occurs within a word, the resultant pronunciation is the only possible standard, as in pens /penz/(Burleigh, 2011, p.89). However, this paper is going to discuss the manners, types, forms and the importance of assimilation.

\section{MANNER OF ASSIMILATION}

After generally introducing the term assimilation, it is time to see how many manners of assimilation there are. Assimilation is of many manners. It includes progressive, regressive and coalescent assimilation (Gimson 2001, p.281), cited in (Jolayemi, 2010, p.100).

\subsection{Progressive Assimilation}

The first manner of assimilation is called progressive. Progressive assimilation is also known as Preservative assimilation. The assimilation is said to be preservative "when the features of a phoneme are modified by thefeatures of the phoneme immediately before it" (Forel \& Puskás,2005, p.50). In other words, the conditioned sound is preceded by the assimilated sound. Such as simulation is dealt with from left to right.

$$
\begin{aligned}
& \text { / wot iz da tam/ } \Rightarrow \text { [wot } s \text { סे tham] What is the time? } \\
& \text { /Da Jpp z oupn/ } \Rightarrow[0 \text { J Jpp s oupn] The shop is open } \\
& \text { /çak haz bin hra/ } \Rightarrow[\text { [jak s bin ha] Jack has been here } \\
& \text { /wot haz hi dan/ } \Rightarrow[\text { wot s hi dsn] What has he done }
\end{aligned}
$$

\footnotetext{
${ }^{1}$ Corresponding Author: hamada_shehdeh2000@hotmail.com
} 


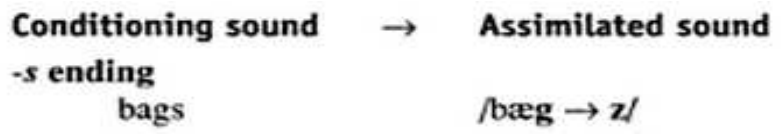

Examples of preservative assimilation of voicelessness from English (RP) can be seen in the following pronunciations of is and has (Laver, 1994, p.383):

In the word level, progressive assimilation can occur, as well. For instance, for the plural -sending, the voiced /g/ of bags conditions the voiced form of the $-\mathrm{s}$ ending, causing it to be pronounced /z/ (CelceMurcia et al, 1996, p.160)

\subsection{Regressive Assimilation}

The second manner of assimilation is regressive. Regressive assimilation is the opposite of progressive and can be called anticipatory. It can be defined as "the change in phoneme characteristics due to influence of a sound occurring later in the word." (Garn-Nunn \& Lynn, 2004, p.111). Therefore, regressive assimilation occurs when the features of a phoneme are modified by those of the phoneme immediately following it (Forel \& Puskás, 2005, p.50).

To illustrate, the sound $/ \mathrm{n} /$ becomes $/ \mathrm{y} /$ under the influence of the voiceless velar plosive $/ \mathrm{k} /$. This occurs in words such as tank/tæyk/,think/@ink/, bank /bæyk/. These words show the changes from/n/ to $/ \mathrm{l} /$ because of the anticipatory articulation of $/ \mathrm{k} /$, which indeed, precedes $/ \mathrm{n} /$ (Jolayemi, 2010, p.101). To examine more examples, see Appendix A.

\subsection{Coalescent Assimilation}

The third type of assimilation is the coalescent assimilation which occurs when there is a fusion. This process causes a sound to change by merging two contiguous phonemes into another phoneme different from the two coalesced sounds. In English coalescence occurs when a morpheme final alveolar plosive or fricative $/ \mathrm{t}$, $\mathrm{d} /$ or $/ \mathrm{s}, \mathrm{z} /$ is followed by [j], a palato - alveolar 3 fricative results, mostly when the segment is followed by the suffix "-ion" (Eka et al. 2010, p.66). A typical example is televise + ion. In the interaction between /s/ and /I/, that occurs while turning the verb to the noun form, results in /3/, which gives /tclivizn/ (Jolayemi, 2010, p.101).

See Appendix B for more examples.

\section{FORMS OF ASSIMILATION}

Although assimilation can be progressive, regressive or coalescent, it has two forms: full assimilation and partial assimilation (Ofulue et al, 2010). When the sound totally adopts another sound, it is called full or complete assimilation. When the sound partially adopts the properties of other sounds, it is called partial or contact assimilation.

\subsection{Full Assimilation}

Full assimilation is also known as complete assimilation. As mentioned previously, a sound may change and become like another. This conversion might be partial or complete. What is meant by complete assimilation is that a sound is totally affected by a neighboring sound in which both sounds become one, or become identical. For example, the phrase / ðæt pless/ becomes / ðæp pless/ (Ladefoged, 2006). It is clear that the /t/ sound is totally, or completely, assimilated to the $/ \mathrm{p} /$ sound and becomes identical to the one in the next word.

\subsection{Partial Assimilation}

assimilation of soundsdoesn'talwaysoccurcompletely. Sometimes, soundspartially assimilate with the surrounding sounds that the influenced sound acquires some properties from other sounds. In other words, partial assimilation involves just one feature of a segment (Ofulue et al., 2010, p.50).

It is noticed by A.Ali (2012, pp. 151-152) that "most assimilations are partial assimilations in which the assimilated sound becomes only more similar, but not identical, to the influencing sound. Partial assimilation can also refer to another assimilation which is called contact assimilation in which the two sounds involved are directly adjacent. For example, the phrase 'ten pikes' is pronounced as /tembaiks/ instead of /ten baiks/ in colloquial speech. Here, the alveolar sound $/ \mathrm{n} /$ changes to $/ \mathrm{m} /$ which is a bilabial sound under the influence of/b/ which is also a bilabial sound." 


\section{TYPES OF ASSIMILATION}

It is noticed that the differences between consonants are of three types: differences in place of articulation, differences in manner of articulation and differences in voicing. Therefore, when a sound assimilates with another sound, the place, manner and voicing of the resulted new sound change depending on the features of the surrounding sounds.

\subsection{Assimilation of Place}

First, when a sound changes its place of articulation to another place, it is called assimilation of place. This change of place depends on the place of articulation of the neighboring sounds. Assimilation of place is of three types: alveolar stops, alveolar fricatives and alveolar syllabic nasals (Lecumberri \& Maidment 2000, p.55). Let's discuss the main details.

\subsubsection{Alveolar Stops Assimilation}

Assimilation of this kind is a regressive assimilation (Roach, 1998). Hence, /t/, /d/ and /n/ tend to change their place of articulation to a position nearer to that of the following sound. In other words, alveolar stops /t, d, n/ may become bilabial if followed by bilabial consonants $/ \mathrm{p}, \mathrm{b}, \mathrm{m} /$, or they may become velar stops $/ \mathrm{k}, \mathrm{g} /$ if they are followed by velars $/ \mathrm{k}, \mathrm{g} /$. Though they assimilate, they don't change the irvoicing (Lecumberri \& Maidment 2000). The following table shows how alveolar sounds become bilabials and velar stops.

Table1. Alveolar Stops Assimilation

\begin{tabular}{|l|l|l|l|}
\hline Alveolar Stops & Velar Stops & Bilabials & Examples \\
\hline$[\mathrm{t}]$ becomes & $/ \mathrm{k} /$ & $/ \mathrm{p} /$ & $\begin{array}{l}\text { that car: ðæt } \mathrm{k}: \square \text { ðæk k : } \\
\text { that man: ðæt mæn: } \square \text { ðæp mæn }\end{array}$ \\
\hline$[\mathrm{d}]$ becomes & $/ \mathrm{g} /$ & $/ \mathrm{b} /$ & $\begin{array}{l}\text { Bad girl: bæd g3:1 } \square \text { bæg g3:l } \\
\text { Bad boy: bæd bor } \square \text { bæb bo }\end{array}$ \\
\hline$[\mathrm{n}]$ becomes & $/ \mathrm{g} /$ & $/ \mathrm{m} /$ & $\begin{array}{l}\text { Ten keys: ten kI:z } \square \text { tey kI:z } \\
\text { Ten pens: ten penz } \square: \text { tem penz }\end{array}$ \\
\hline
\end{tabular}

\subsubsection{Alveolar Fricatives Assimilation}

The alveolar stop /s/ may become post alveolar fricative / $/$ / as in this shoe (ðIs $\int \mathrm{u}$ : $\square \partial_{\mathrm{I}} \int \mathrm{\int u}$ :)and /z/ may become /z/

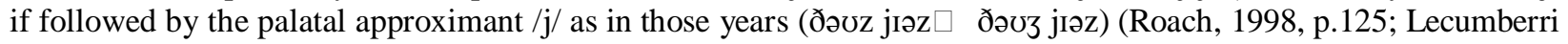
\& Maidment, 2000).

\subsubsection{Alveolar Syllabic Nasal Assimilation}

Assimilation of this kind is a progressive assimilation. Thus, $/ \mathrm{n} /$ could become bilabial $/ \mathrm{m} /$ when preceded by a bilabial or could become velar $/ \mathrm{y} /$ if preceded by a velar plosive in the same word and followed by a consonant in the same or next word or by a pause (Lecumberri \& Maidment 2000, p.56).

Examples of which are:

open /'oupən/ $\square$ /'əupn/ $\square /$ 'əoupm/.

bacon / 'berkən/ $\square /$ 'berk n/ $\square /$ 'berky/

\subsection{Assimilation of Manner}

Second, like assimilation of place, assimilation of manner refers to two neighboring sounds becoming similar in their manner of articulation. This happens in coalescence when, in connected speech, two adjacent sounds are merged to form a new sound (Gut, 2009, p.35).

Additionally, it is usually heard in very rapid speech, or very informal situation and it can be either progressive or regressive (Burleigh, 2011). Clear examples of this type are difficult to seek since it involves a change from a stronger consonant (one making a more substantial obstruction to the flow of air) to a weaker one (Roach, 2001, p.55).

Examples of progressive and regressive assimilation are found in Burleigh (2011, p.93). An example the progressive could be in shut your mouth when pronounced rapidly. Here, the approximant /j/ can be articulated with a narrow gap between the speech organs under the influence of the preceding / $/$ /. An example of the regressive could be in that side /ðæs sard/ and in good night/gon nart/. In /ðæs sard/, the plosive 
/t/ becomes fricative /s/, and in /gun nart/, the plosive /d/ becomes nasal /n/.

Generally, according to Burleigh, assimilation of manner tends to be regressive with less obstruction of air.

\subsection{Assimilation of Voice}

Finally, it is difficult to produce a consonant cluster, in many languages including English, with different voicing values for the consonants, particularly if the consonants are obstruent's (fricatives or plosives) (Nathan, 2008, p.78). When two consonants are in the coda, they have to agree in voicing either voiced or voiceless. In other words, in a cluster of two consonants differing in voicing, the second consonant has to agree in voicing with the preceding one (Fortson, 2005, p.63). Assimilation of voice is of two forms: across morpheme boundaries and across word boundaries.

\subsubsection{Assimilation of Voice across Morpheme Boundaries}

This type of assimilation is represented in noun plural marker, the possessive and the singular present tense which always agree in voicing with the preceding obstruent consonant (regressive). Recall that the voiced /z/ of the English regular plural suffix is changed to [s] after a voiceless sound. Similarly, the voiced /d/ of the English regular past-tense suffix is changed to [t] after a voiceless sound. In these cases, the value of the voicing feature goes from [+voice] to [-voice] or from [-voice] to [+voice] because of assimilation to the $[-+$ voice] feature of the final consonant of the stem (Fromkin et al., 2011, p.287).

Examples of such assimilation are: 8

$\operatorname{dogs} / \mathrm{d} \mathrm{gz} /:$ /s/ becomes /z/ to agree in voicing with $/ \mathrm{g} /$.

cats / kæts/: /s/ becomes /s/ to agree in voicing with /t/.

killed / kıld/: /d/ agrees in voicing with /l/.

voiced / vorst/: /t/ agrees in voicing with /s/.

The following table shows the alternation of the plural suffix $[\mathrm{s}]$ depending on the surrounding sounds.

Table2. Alternations of $[z]$

[s] becomes

\begin{tabular}{|l|l|l|}
\hline$/ \mathrm{s} /$ if preceded by & /z/ if preceded by & /Iz/ if preceded by \\
\hline a voiceless non-sibilant & a voiced non-sibilant & sibilants \\
{$[\mathrm{p}],[\mathrm{t}],[\mathrm{k}],[\mathrm{f}],[\theta]$} & {$[\mathrm{b}],[\mathrm{d}],[\mathrm{g}],[\mathrm{l}],[\mathrm{m}],[\mathrm{n}],[\mathrm{r}],[\mathrm{v}],[\mathrm{j}]$} & $[\mathrm{s}],[\mathrm{z}],[\mathrm{J}],[\mathrm{z}],[\mathrm{t}]],[\mathrm{d} z]$ \\
\hline
\end{tabular}

From the table, it is noticed that $[\mathrm{s}]$ is pronounced as $/ \mathrm{s} /$ if preceded by a voiceless non-sibilant sound (cats), pronounced as $/ \mathrm{z} /(\mathrm{dogs})$ if preceded by a voiced non-sibilant sound, and pronounced as /Iz/ (judges /d $3 \wedge \mathrm{d} 3 \mathrm{z} / /$ ) if preceded by a sibilant sound. Rules can be devised:

\subsubsection{Assimilation of Voice across Word Boundaries}

According to Knight (2003, www.rachaelanne.net/teaching/uev/uev4.doc) "in English, only regressive assimilation is found across word boundaries and then only when a voiced word final consonant is followed by a voiceless word initial consonant. It is never the case that a word final voiceless consonant becomes voiced because of a word initial voiced consonant." A clear example demonstrating this kind of assimilation is the assimilation of the voiced $/ \mathrm{v} /$ with the voiceless /t/ in have to /hæv to/ $\square / \mathrm{hæf}$ to/.

\section{ASSIMILATION OF THE DEFINITE ARTIClE THE - AL-/OL/ IN STANDARD ARABIC}

It is known for Arab learners that letters are categorized in two groups, solar and lunar letters depending on the ability to assimilate with the following sounds . For instance, in a word like 'al- shamssun', the/l/sound is totally assimilated with the following sound 'sh', so the resultant pronunciation of the word is /ashshams/. Thus, the sun letters are said to assimilate and the letter is doubled, where the moon letters are not. The sun and the moon letters are presented in Table 3 below (http://en.wikipedia.org/wiki/Sun_and_moon_letters).

So, when the definite article comes before any solar letter, assimilation takes place. Let'smakeit clear by adding the definite article al to the solar letters: al + solar letters: al + $\mathrm{t}$ becomes at-t, al + th becomes ath-th, al $+\mathrm{d}$ becomes add etc. Let's see some arabic words: 
Table3. Solar and Lunar Letters of Arabic.

\begin{tabular}{|c|c|c|c|c|c|c|c|c|c|c|c|c|c|c|}
\hline Sun letters & $ت$ & $\stackrel{ث}{ث}$ & د & j & $J$ & j & س & ش & ص & ض & b & ظ & J & ن \\
\hline & $\mathrm{t}$ & $\theta$ & $\mathrm{d}$ & ð & $\mathrm{r}$ & $\mathrm{Z}$ & $\mathrm{s}$ & & $s^{5}$ & $d^{\top}$ & $t^{5}$ & $\partial^{\gamma}$ & 1 & \\
\hline Sun letters & $ت$ & $\mathscr{f}$ & د & ذ & $J$ & j & س & ش & ص & ض & $b$ & ظ & J & ن \\
\hline & & & & & & & & & & $\mathrm{k}$ & $\mathrm{m}$ & W & $\mathrm{j}$ & $\mathrm{h}$ \\
\hline
\end{tabular}

/d :r/(home)+/əl/=/əd-d :r/(totalassimilation).

/naorəs/ (seagull) + /əl/= / ən-naorəs (total assimilation).

Such assimilation occurs completely when a noun begins with coronal consonants (Hall, 1997, p.34). Sun letters in the Arabic language are coronal consonants so that they totally assimilate with the sound /l/ in the definite article al if the sound is followed by one of these coronals; the moon letters are non-coronals (Heselwood \& Watson, 2013). The reason of such total assimilation is that $/ 1 /$ in Arabic is a coronal consonant so that it assimilates with other coronals. Nevertheless, Heselwood \& Watson $(2013$, p.49) reject that there is an assimilation between the definite article (al) and coronal consonants:

'We have argued that the geminates which occur in definite article plus coronal consonant constructions are not the result of synchronic assimilation and shouldinsteadberegardedas'true'geminates,notassimilatorygeminates.'

Therefore, it is more logical to say that there is no assimilation between (l) and coronal consonants. The better term is 'truegeminates'. The results are that the (l) sound disappears and is not pronounced when followed by coronal consonants.

\section{HISTORICAL ASSIMILATION}

What is discussed previously is called contextual assimilation. It means that the assimilation of consonants is subject to the environment of sounds. However, historical assimilation has taken place in the development of a language. A sound in a word may change to another sound that shares the same place, manner or voicing because of the development of a language. For example, the word 'ant' / ænt/ in the thirteenth and fourteenth centuries was pronounced / æmətə/ and later /æmtə/ and /æmt/. Thus, the spelling with $/ \mathrm{n} / \mathrm{instead}$ of $/ \mathrm{m} /$ first appeared in the fifteenth century which clearly indicating the change to the modern pronunciation /ænt/ (Jones 1972, p.217) cited in A.Ali (2012, p.149).

\section{THE IMPORTANCE OF ASSIMILATION}

When a sound adopts features of another sound, the process of articulation becomes much easier. This idea is confirmed by McMahon (2002, p.4) and Burleigh (2011, p.90). According to them, assimilation involves ease of articulation pressures and it is an important means of making pronunciation easier. Additionally, Eka et al. (2010, p.64) provide three functions of assimilation: to save time, to anticipate other sounds and to ease articulation. Thus, one can conclude that the importance of assimilation is to make the process of speech easier.

\section{CONCLUSION}

Assimilation is one of the phonological processes in which a sound undergoes a change based on the phonological environments (Eka et al., p.2010). It has many types and forms including place, manner, voicing, progressive, regressive, and coalescent that can be either full or partial assimilation. Moreover, assimilation can occur within a word level or within word boundaries. Furthermore, assimilation occurs because of the development of languages, and under the effects of the surrounding sounds. This leads us to say that the major function of assimilation is to ease articulation.

\section{REFERENCES}

[1] A.Ali, Z.(2012). A Phonological Study of English and Arabic Assimilation: A Contrastive Study. Journal of College of Languages. (25), 148-172.

[2] Burleigh, P. (2011). A Manual of English Phonetics and Phonology. Frankfurt: Gunter NarrVerlag. 
[3] Celce-Murcia, M., \& Brinton, D., \&Goodwin, J. (1996). Teaching Pronunciation: A Reference for Teachers of English to Speakers of Other Languages. Cambridge:Cambridge University Press.

[4] Eka, D., \& Daniel, I., \& Egbokhare, F., \& Iyere, Th. (2010). Introduction to Phonetics and Phonology of English. Lagos: Nigeria: National Open University of Nigeria.

[5] Forel, C., \& Puskás, G. (2005). Phonetics and Phonology: Reader for First Year English Linguistics. Retrieved on March, 9,2014, from http://faculty.mu.edu.sa/public/uploads/1367177870.6546PHONETICS\%20AND\%20PHONOLOGY.pdf.

[6] Fortson, P. (2005). Indo-European Language and Culture: An Introduction. Oxford: UK:Blackwell Publishing.

[7] Fromkin, V., \& Rodman, R., \& Hyams, N. (2011). An Introduction to Language. Boston:USA: Wadsworth.

[8] Garn-Nunn, P., \& Lynn, J. (2004). Calvert's Descriptive Phonetics. New York: Thieme Medical Publisher.

[9] Gimson, A. C. (2001). Pronunciation of English. London: UK: A Hodder Arnold Publication.

[10] Gut, U. (2009). Introduction to English Phonetics and Phonology. Frankfurt: Peter Lang.

[11] Hall, T. (1997). The Phonology of Coronals. Amsterdam: John Benjamins Publishing.

[12] Heselwood, H., \& Watson, J. (2013). The Arabic Definite Article Does Not Assimilate.LWPLP, (18), $34-53$.

[13] Jolayemi, D. (2010). The Phonology of English. Nigeria: National Open University of Nigeria.

[14] Jones, D. (1972). Outline of English Phonetics. Cambridge: W. Heffer.

[15] Knight,R.(2003).Understanding English Variation. Retrieved on March, 9, 2014, from www.rachaelanne.net/teaching/uev/uev4.doc.

[16] Ladefoged, P. (2006). A Course in Phonetics. Boston: Thomson Wadsworth.

[17] Laver, J. (1994). Principles of Phonetics. Cambridge: Cambridge University Press.

[18] Lecumberri, M., \& Maidment, J. A. (2000). English Transcription Course. London, UK: Routledge Publisher.

[19] McMahon, A. (2002). An Introduction to English Phonology. Edinburgh: Edinburgh University Press.

[20] Nathan, G. (2008). Phonology: A Cognitive Grammar Introduction. Amsterdam: John Benjamins Publishing.

[21] Ofulue, Ch. \& Urua, E., \& Egbokhare, F. (2010). Introduction to Linguistics II. Nigeria: National Open University of Nigeria.

[22] Oxford Dictionary. (2008).Oxford, UK: Oxford University Press.

[23] Roach, P. (1998). English Phonetics and Phonology. UK. Cambridge University Press.

[24] Roach, P. (2001). Phonetics. Oxford: Oxford University Press.

Sites

http://en.wikipedia.org/wiki/Sun_and_moon_letters 14

Appendix A Regressive Assimilation

A.Ali, (2012, 50).

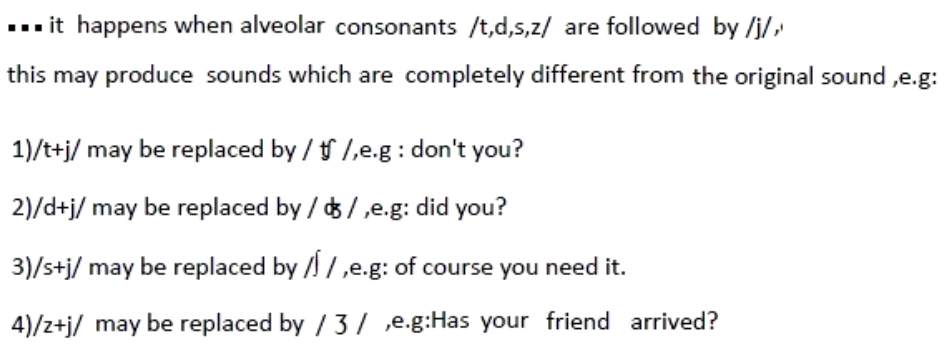

Appendix B Coalescent Assimilation

A.Ali, (2012, 50). 
American Research Journal of English and Literature, Volume 1, Issue 4, 2015

ISSN 2378-9026

1)/p/ replaces /t/ before /p,b,m/,e.g :right place, right man, right book

2)/b/ replaces /d/ before /p,b,m/,e.g: good people, good boy ,good men

3)/m/ replaces /n/ before /p,b, m/ ,e.g: one minute, one bag ,one picture

4)/k/ replaces /t/ before /k,g/,e.g: right coat ,right girl

5)/g/ replaces /d/ before / k,g/,e.g: good game, bad king

$6) / \mathrm{n} /$ replaces $/ \mathrm{n} /$ before $/ \mathrm{k}, \mathrm{g} /$,e.g: one car ,one girl

7) $/ \int /$ replaces $/ s /$ before $/ \int, j /$,e.g: this shirt, this year

8)/ 3 / replaces / $/$ / before / ,j/, e.g: these shirts, these years

9)/mp/ replaces / $\mathrm{nt} /$ before /p,b,m/,e.g: don't be angry ,don't miss it

10) /mb/ replaces /nd/ before /p,b, $\mathrm{m} /$,e.g:stand by , stand back

11)/nk/ replaces /nt/ before /k,g/ ,e.g: I don't care ,don't go

12)/ng/ replaces /nd/ before / k,g/ ,e.g: stand guard 